\title{
LIQUEFACTION OF UNSATURATED SAND CONSIDERING THE PORE AIR PRESSURE AND VOLUME COMPRESSIBILITY OF THE SOIL PARTICLE SKELETON
}

\author{
Toshiyasu Unno ${ }^{\mathrm{i})}$, Mоtoki Kazama ${ }^{\mathrm{ii})}$, Ryosuke Uzuoka ${ }^{\mathrm{iii}}$ and Noriaki Sento ${ }^{\mathrm{iv})}$
}

\begin{abstract}
A series of cyclic triaxial tests of unsaturated soils was conducted to get a better understanding of the general liquefaction state of unsaturated soils. In the tests, cyclic shear strain was applied to fine clean sand with the same dry density but different initial suction states under the undrained condition. During cyclic shear, the volume change of the soil particle skeleton, the pore air pressure and the pore water pressure were measured continuously. Having used the effective stress defined by Bishop (Bishop et al., 1963), where the net stress and suction contribute to the effective stress, our test results showed that unsaturated sand specimens with quite a low degree of saturation lose their effective stress due to cyclic shear. At a zero effective stress state, unsaturated specimens behaved similarly to liquids in much the same way as saturated specimens. From experimental and theoretical considerations, the zero effective stress state (i.e., liquefaction) for unsaturated sand was found to have been established when both the pore air and water pressures build up to the point where it is equal to the initial total pressure. A volume change of pore air under the undrained condition, if a volume change of pore water is negligible, is equal to that of the soil particle skeleton. Therefore, it can be concluded that the liquefaction of unsaturated soil generally depends on the volume compressibility of the soil particle skeleton and the degree of saturation. On the other hand, according to the ideal gas equation of Boyle-Charles law, the volume change required to bring about a zero effective stress state can be calculated from the initial pore air pressure (usually the atmospheric pressure) and the final pore air pressure (the initial confining pressure). Therefore, the liquefaction of unsaturated soils also depends on the initial confining pressure. Based on this concept, the liquefaction potential of unsaturated soil can be evaluated by comparing the volume compressibility of the soil particle skeleton and the volume change of the pore air required to bring about a zero effective stress state.
\end{abstract}

Key words: cyclic shear, liquefaction, pore air pressure, unsaturated soil, volume compressibility (IGC: D3/D7)

\section{INTRODUCTION}

To date, the unsaturated condition has been assumed tacitly safe when subjected to cyclic shear because of the high compressibility of the pore air. Therefore, little attention has been given to determining the shear strength reduction of unsaturated soils subjected to cyclic shear in practical engineering. In fact, in the case of fine clean sand, it is known that the cyclic shear strength of fully saturated soil doubles when the degree of saturation decreases to $90 \%$ under ordinary testing conditions (e.g., Yoshimi et al., 1989; Tsukamoto et al., 2002; Selim et al., 2006). Recently, Okamura et al. (2006) discussed the factors of liquefaction resistance of partially saturated sand in a series of cyclic triaxial tests, by taking the countermeasures to liquefaction into account. Their results con- firmed that the degree of saturation has a significant effect on liquefaction resistance and that amount of liquefaction resistance depends on the initial confining pressure and the initial pore pressure.

While unsaturated soils have been given little attention, earthquake induced mudflow type slope failure has been attracting a lot of attention in recent years. Such failures occur especially in regions covered with volcanic ash sandy soil. The Las Colinas landslide, which occurred during the $2001 \mathrm{El}$ Salvador earthquake and resulted in the deaths of over 500 people, is a typical example (Konagai et al., 2002). The failure of a gentle fill slope consisting of volcanic sandy soil also occurred during the 2003 earthquake in Japan (Uzuoka et al., 2005). According to eyewitnesses' accounts, these slopes failed suddenly during the earthquake and the flowing soil behaved like

i) Postdoctoral Fellow, The National Institute for Rural Engineering, Japan (tunno@affrc.go.jp) (formerly Graduate Student of Tohoku University).

ii) Professor, Department of Civil Engineering, Graduate School of Engineering, Tohoku University, Japan (kazama_motok@civil. tohoku.ac.jp).

iii) Associate Professor, ditto (uzuoka@civil.tohoku.ac.jp).

iv) Research Associate, ditto (nsentoh@civil.tohoku.ac.jp).

The manuscript for this paper was received for review on March 30, 2007; approved on September $20,2007$.

Written discussions on this paper should be submitted before September 1, 2008 to the Japanese Geotechnical Society, 4-38-2, Sengoku, Bunkyo-ku, Tokyo 112-0011, Japan. Upon request the closing date may be extended one month. 
a liquid. Because the slope material had to be under an unsaturated condition from the surface to a certain depth, the authors suspected that unsaturated soil had made a phase transformation from a static condition, as a solid phase, to a fluid-like phase after shaking. In order to clarify the mechanism, fundamental research on unsaturated volcanic soils after subjecting them to cyclic shear has been carried out by the authors (Unno et al., 2006a; Kazama et al., 2006). In these studies, it was shown that a shaking disturbance affects the moisture state of soil, and that the liquefaction potential of unsaturated soil can be evaluated by taking the volume compressibility of the soil particle structure, the degree of saturation and the confining pressure into account. The authors also noted that the water retention capacity of volcanic sandy soil common to such slope failures was of a peculiar nature.

Considering this background, this paper is focused on the general liquefaction state of unsaturated sand, and, in particular, presents the results of cyclic shear tests on unsaturated fine clean sand. In order to determine the suction behavior, constant measurements of the volume change in the soil particle skeleton, the pore air pressure and the pore water pressure were taken during cyclic shear. With the exception of Becker et al. (2002) and Nakayama et al. (2003) we are not aware of any other research which has employed this kind of test. Nakayama used weathered granite soil to observe suction behavior during cyclic shear. Our findings in this study, obtained from experimental and theoretical considerations, have made it possible to propose a new method to evaluate the liquefaction potential of unsaturated soil.

\section{CYCLIC TRIAXIAL TEST OF UNSATURATED SOILS}

\section{Physical Properties of Soil}

From a practical engineering point of view, when discussing the liquefaction of soils under the unsaturated condition, the target soil should be one with a high water retention capacity. However, in this study, a fine clean sand known as Toyoura sand was used as the testing material in order to explain the general liquefaction state of unsaturated soils. Other publications are available for reference purposes with regard to tests carried out on volcanic sandy soil (Kazama et al., 2006; Unno et al., $2006 \mathrm{~b}$ ). Figure 1 shows the grain size distributions of the Toyoura sand used in this study, which has no fine content and a specific gravity of 2.643 . The void ratio in densest state and loosest state are 0.609 and 0.967 respectively. For comparison purposes, the curve of the volcanic sand is also shown in the figure. The specific gravity of the volcanic sand is 2.478 in view of the porous nature of the soil particles.

Figure 2 illustrates the relationship between the suction head and the degree of saturation following a drying path of Toyoura sand and volcanic sand. The open marks in the figure indicate the initial suction conditions before cyclic shear. Suction during the tests was controlled using

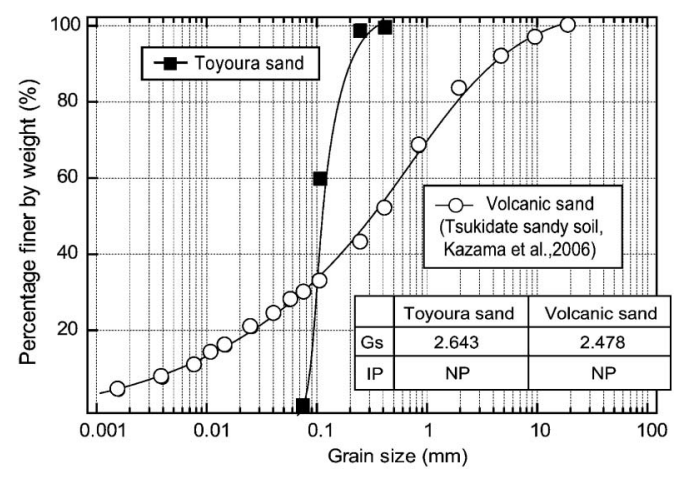

Fig. 1. Grain size distribution and physical properties of testing soil sample

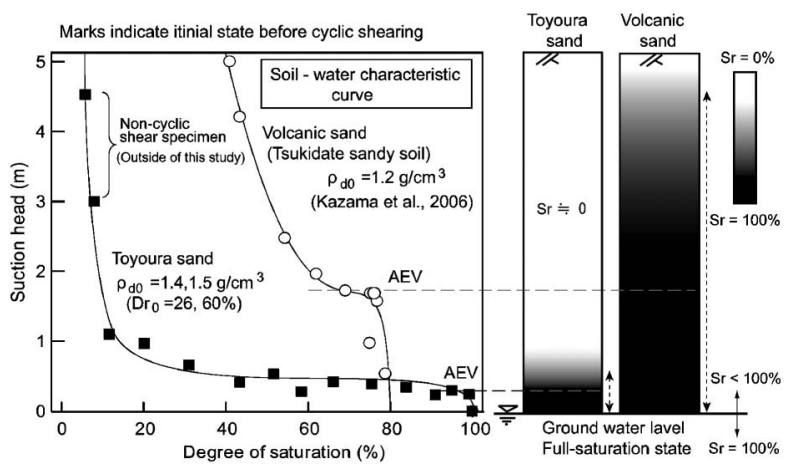

Fig. 2. Relationship between suction and degree of saturation

the axis translation technique. It is likely that the air entry value (AEV) of Toyoura sand is about $4-5 \mathrm{kPa}$, and that of volcanic sand is about $17 \mathrm{kPa}$. In the right side of the figure, a schematic diagram corresponding to actual ground water conditions is shown. This figure clearly illustrates that volcanic sand has a thicker unsaturated zone with high water content than Toyoura sand. This is one of the reasons why volcanic sand is of so much more importance from a practical engineering point of view.

\section{Testing Apparatus}

Figure 3 shows the schematic diagram of testing apparatus for cylindrical specimens $50 \mathrm{~mm}$ in diameter and $100 \mathrm{~mm}$ in height. A glass fiber filter and ceramic disk with an AEV of $200 \mathrm{kPa}$ were installed at the top and bottom of specimen, respectively. A step motor was used for strain-controlled cyclic loading, and the volume change of the whole specimen was measured directly from the differential pressure meter between the inner cell and outer water head, and its measurement capacity was $25 \%$ volumetric strain. Continuous measurements of the pore water and air pressure were taken to obtain the soil suction. The pore air pressure during cyclic shear was measured by the air transducer attached directly above the specimen. A solenoid valve was attached in order to avoid the effect of aerial compressibility in the pipe line. The volume of the inner pipe from the top of the specimen to the solenoid valve was $0.18 \mathrm{~cm}^{3}$, which is considered small enough to allow for accuracy. 


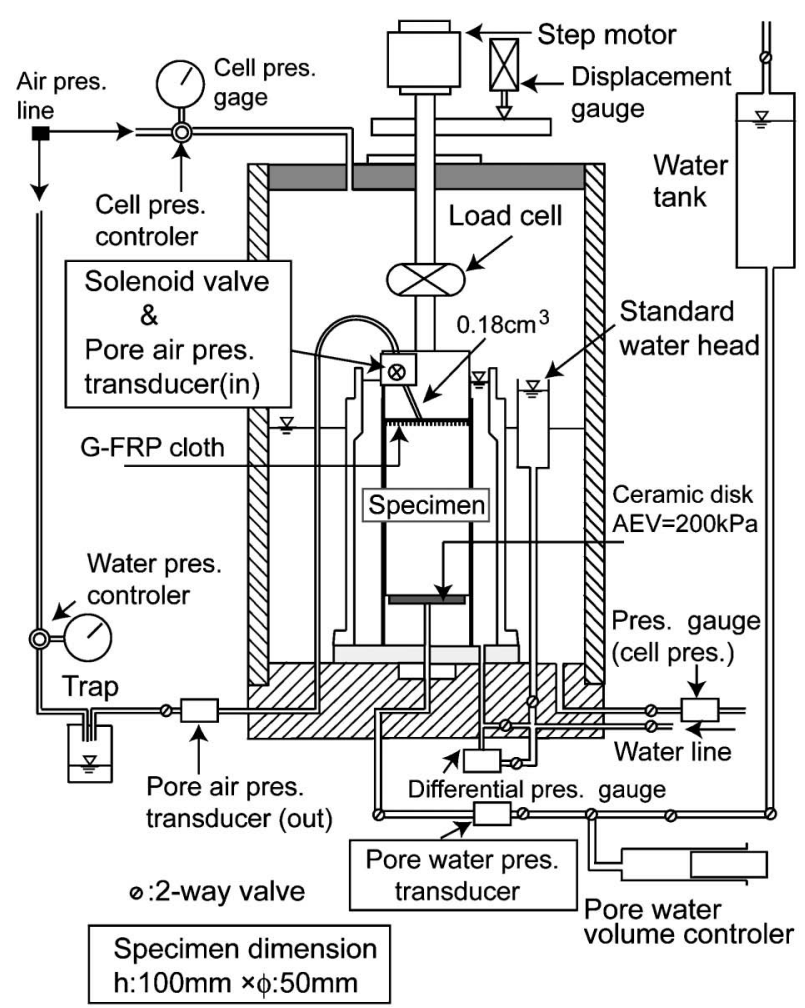

Fig. 3. Configuration of equipment of the unsaturated triaxial test system

\section{Specimen Preparation Method of Initial Stress Condition}

The initial stress condition including the soil water condition was achieved in the following way. To begin with, $75 \mathrm{~cm}^{3}$ of water was out in the mold. This corresponds to about $95 \%$ saturation in the case of $D_{\mathrm{r} 0}=26 \%$, and about $25 \%$ water content when the sand is put in. Next, dried sand is dropped into the mold through the air. The amount of the sand and falling height were decided in order to make initial relative density $60 \%$ and $26 \%$ from preliminary test. In other words, the procedure is exactly the same as ordinary cyclic loading test.

During this process, the sand absorbs the water and the specimen attains a uniform moisture state. In the consolidation process, the confining pressure is applied step by step, as shown in Fig. 4. Because of the difficulty in controlling the air pressure to achieve the prescribed initial degree of saturation, we controlled the drained water volume from the initial condition (i.e., through the drying process). That is, when the target degree of saturation was achieved during the consolidation process, the water route was closed and the air pressure was controlled to achieve suction at the prescribed value, as shown in Fig. 4. There are some cases where the excess pore water pressure builds up when pore water valve is closed on the condition that pore water in specimens is not sufficiently stabilized. Then pore air pressure and the cell pressure are controlled to be the initial condition. In the test series, two initial suction conditions are simulated considering the actual ground conditions, as shown in Fig. 4. Table 1 indicates the condition of series a and $c$, in which the initial pore water pressure is equal to the atmospheric pres-

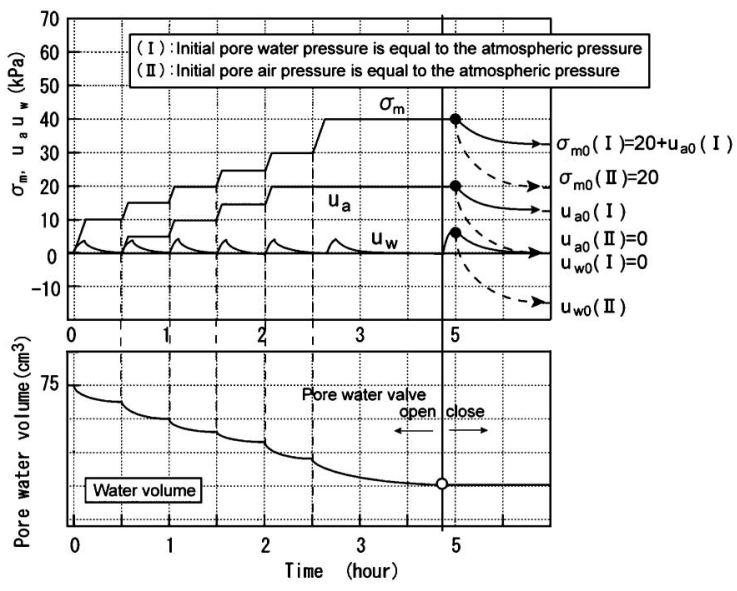

Fig. 4. Example of the time history of cell pressure and pore air pressure and drained water volume during consolidation process

sure $98 \mathrm{kPa}$ and the other condition of series $\mathrm{b}$ also is shown in Table 1 , in which the initial pore air pressure is equal to atmospheric pressure $98 \mathrm{kPa}$.

The full saturation specimen's test cases $(a-1, c-1)$ had the consolidation process like the ordinary cyclic shear test method (that is, this test was same as the liquefaction test and not used with the glass fiber filter and the ceramic disk of unsaturated triaxial test system). In order to achieve full saturation condition, a back pressure of 100 $\mathrm{kPa}$ was applied to the specimen.

\section{Drainage Condition}

In order to study the cyclic behavior of unsaturated sand from various initial suction conditions, several series of strain-controlled cyclic triaxial tests were conducted under the undrained condition. For our purposes, an undrained condition is one in which the migration of pore water and air to the outside of specimen is not allowed during cyclic shear. In other words, this condition assumes that the actual seismic loading rate is more rapid than the migration rate of pore water and air, as is the case under saturated conditions. Because the permeability of pore air is generally smaller than that of water under the full saturation condition, this assumption is considered reasonable.

\section{Loading Condition}

After simulating the initial isotropic stress condition described above, cyclic axial strain was applied. Figure 5 shows the cyclic shear history used. As can be seen in Fig. 5 , these tests were under step loading-each axial strain single amplitude of the sinusoidal wave was $0.2,0.4,0.8$, 1.6, and 2.0 with every ten cycles. The concept of strain controlled cyclic shear test is shown in the literature by the second author (Kazama et al., 2000). The frequency of the sinusoidal wave is $0.005 \mathrm{~Hz}$. This loading rate is slow enough to achieve an equilibrium condition between air and water pressure. This point was confirmed from preliminary tests. 
Table 1. Initial condition after consolidation process (Before cyclic loading process)

(a) $D_{\mathrm{r} 0}=60 \%$

\begin{tabular}{|c|c|c|c|c|c|c|c|c|c|c|c|c|c|}
\hline Sample & $\begin{array}{c}\text { Case } \\
\text { No }\end{array}$ & $\begin{array}{l}\text { Suction } \\
S_{0}(\mathrm{kPa})\end{array}$ & $\begin{array}{c}\text { Pore water } \\
\text { pressure }{ }^{* 1} \\
u_{\mathrm{w} 0}(\mathrm{kPa})\end{array}$ & $\begin{array}{l}\text { Pore air } \\
\text { pressure }{ }^{\star 1} \\
u_{\mathrm{a} 0}(\mathrm{kPa})\end{array}$ & $\begin{array}{c}\text { Water } \\
\text { content } \\
w_{0}(\%)\end{array}$ & $\begin{array}{l}\text { Dry density } \\
\rho_{\mathrm{d} 0}\left(\mathrm{~g} / \mathrm{cm}^{3}\right)\end{array}$ & $\begin{array}{c}\text { Void } \\
\text { ratio } \\
e_{0}\end{array}$ & $\begin{array}{c}\text { Degree of } \\
\text { saturation } \\
S r_{0}(\%)\end{array}$ & $\begin{array}{c}\text { Mean effective }{ }^{\star 2} \\
\text { principal stress }(\mathrm{kPa}) \\
\sigma_{\mathrm{m} 0}^{\prime}=\left(\sigma_{\mathrm{m} 0}-u_{\mathrm{a} 0}\right)+\chi s_{0}\end{array}$ & $\begin{array}{c}\text { Cell } \\
\text { pressure } \\
\sigma_{\mathrm{m}}(\mathrm{kPa})\end{array}$ & $\begin{array}{l}\text { Net stress } \\
\sigma_{\text {net } 0}(\mathrm{kPa})\end{array}$ & $\begin{array}{l}\text { Volume } \\
\text { of air } \\
V_{\mathrm{a} 0}\left(\mathrm{~cm}^{3}\right)\end{array}$ & $B$-value \\
\hline \multirow{16}{*}{$\begin{array}{c}\text { Toyoura } \\
\text { asnd } \\
\left(D_{\mathrm{r} 0}=60 \%\right)\end{array}$} & $a-1$ & 0.0 & $0.0(98.0)$ & $0.0\left(\begin{array}{ll}0.0\end{array}\right)$ & 27.9 & 1.52 & 0.74 & 100 & 20.5 & $120(218)^{\star 3}$ & - & 0 & 0.99 \\
\hline & $a-2$ & 2.6 & $0.0(98.0)$ & $2.6(100.6)$ & 26 & 1.51 & 0.75 & 92.0 & 20.3 & $20.4(118.4)$ & 17.8 & 5.4 & 0.4 \\
\hline & $a-3$ & 3.2 & $0.0(98.0)$ & $3.2(101.2)$ & 25.2 & 1.52 & 0.74 & 94.8 & 20.6 & $21.4(119.4)$ & 18.2 & 4.3 & 0.3 \\
\hline & $a-4$ & 6.0 & $0.0(98.0)$ & $6.0(104.0)$ & 23.5 & 1.52 & 0.74 & 84.6 & 22.3 & $23.2(121.2)$ & 17.2 & 11.5 & 0.06 \\
\hline & $a-5$ & 5.0 & $0.0(98.0)$ & $5.0(103.0)$ & 21.8 & 1.52 & 0.74 & 78.3 & 22.0 & $23.9(121.9)$ & 18.9 & 17.3 & 0.07 \\
\hline & $a-6$ & 3.9 & $0.0(98.0)$ & $3.9(101.9)$ & 18.1 & 1.53 & 0.73 & 64.8 & 22.4 & $24.1(122.1)$ & 20.2 & 28.4 & 0.13 \\
\hline & $a-7$ & 5.3 & $0.0(98.0)$ & $5.3(103.3)$ & 14.8 & 1.52 & 0.74 & 51.6 & 21.1 & $23.7(121.7)$ & 18.4 & 38.9 & 0.03 \\
\hline & $a-8$ & 6.6 & $0.0(98.0)$ & $6.6(104.6)$ & 8.7 & 1.52 & 0.74 & 31.2 & 21.0 & $25.3(123.3)$ & 18.7 & 55.9 & 0.01 \\
\hline & a-9 & 10.9 & $0.0(98.0)$ & $10.9(108.9)$ & 9.4 & 1.54 & 0.72 & 20.2 & 21.2 & $30.0(128.0)$ & 19.1 & 53.9 & 0.02 \\
\hline & $a-10$ & - & - & - & 0 & 1.52 & 0.74 & 0 & 20.0 & $20.0(118.0)$ & - & 81.9 & - \\
\hline & a-11 & 3.2 & $0.0(98.0)$ & $3.2(101.2)$ & 22.8 & 1.53 & 0.73 & 82.0 & 62.7 & $62.8(160.8)$ & 59.6 & 13.0 & 0.08 \\
\hline & $a-12$ & 2.7 & $0.0(98.0)$ & $2.7(100.7)$ & 21.8 & 1.53 & 0.72 & 79.6 & 61.0 & $63.4(161.4)$ & 60.7 & 16.9 & 0.02 \\
\hline & a-13 & 3.8 & $0.0(98.0)$ & $3.8(101.8)$ & 12.8 & 1.53 & 0.73 & 46.4 & 60.0 & $62.5(160.5)$ & 58.7 & 43.8 & 0.01 \\
\hline & $\mathrm{b}-1$ & 3.7 & $-3.7(94.3)$ & $0.0(98.0)$ & 26.6 & 1.52 & 0.74 & 95.2 & 20.0 & $20.0(118.0)$ & 20.0 & 2.7 & 0.40 \\
\hline & b-2 & 3.1 & $-3.1(94.9)$ & $0.0(98.0)$ & 25.3 & 1.52 & 0.74 & 89.9 & 22.8 & $20.0(118.0)$ & 20.0 & 7.0 & 0.09 \\
\hline & b-4 & 3.8 & $-3.8(94.2)$ & $0.0(98.0)$ & 11.5 & 1.53 & 0.73 & 39.5 & 23.2 & $20.0(118.0)$ & 20.0 & 47.5 & 0.02 \\
\hline
\end{tabular}

$※ 1$ The figure of the parenthesis is the absolute pressure, which is added the atmospheric pressure $98 \mathrm{kPa}$ to the mesured pressure. $※ 2$ Effective stress of Unsaturated soil based on Bishop's equation, parameter of suction $\chi$ represents the degree of saturation. $※ 3$ Sample was saturated with back pressure of $100 \mathrm{kPa}$.

(b) $\quad D_{\mathrm{r} 0}=26 \%$

\begin{tabular}{|c|c|c|c|c|c|c|c|c|c|c|c|c|c|}
\hline Sample & $\begin{array}{c}\text { Case } \\
\text { No }\end{array}$ & $\begin{array}{l}\text { Suction } \\
S_{0}(\mathrm{kPa})\end{array}$ & $\begin{array}{c}\text { Pore water } \\
\text { pressure }{ }^{* 1} \\
u_{\mathrm{w} 0}(\mathrm{kPa})\end{array}$ & $\begin{array}{c}\text { Pore air } \\
\text { pressure }{ }_{1} \\
u_{\mathrm{a} 0}(\mathrm{kPa})\end{array}$ & $\begin{array}{l}\text { Water } \\
\text { content } \\
w_{0}(\%)\end{array}$ & $\begin{array}{l}\text { Dry density } \\
\rho_{\mathrm{d} 0}\left(\mathrm{~g} / \mathrm{cm}^{3}\right)\end{array}$ & $\begin{array}{c}\text { Void } \\
\text { ratio } \\
e_{0}\end{array}$ & $\begin{array}{c}\text { Degree of } \\
\text { saturation } \\
S r_{0}(\%)\end{array}$ & $\begin{array}{c}\text { Mean effective }{ }^{※ 2} \\
\text { principal stress }(\mathrm{kPa}) \\
\sigma_{\mathrm{m} 0}^{\prime}=\left(\sigma_{\mathrm{m} 0}-u_{\mathrm{a} 0}\right)+\chi s_{0}\end{array}$ & $\begin{array}{c}\text { Cell } \\
\text { pressure } \\
\sigma_{\mathrm{m}}(\mathrm{kPa})\end{array}$ & $\begin{array}{l}\text { Net stress } \\
\sigma_{\text {net } 0}(\mathrm{kPa})\end{array}$ & $\begin{array}{l}\text { Volume } \\
\text { of air } \\
V_{\mathrm{a} 0}\left(\mathrm{~cm}^{3}\right)\end{array}$ & $B$-value \\
\hline \multirow{9}{*}{$\begin{array}{c}\text { Toyoura } \\
\text { asnd } \\
\left(D_{\mathrm{r} 0}=26 \%\right)\end{array}$} & $\mathrm{c}-1$ & 0 & \multirow{9}{*}{$0.0(98.0)$} & $0 \quad(98.0)$ & 30.7 & 1.46 & 0.81 & 100 & 20.0 & $120(218)^{\star 3}$ & 0 & 0 & 1.0 \\
\hline & $c-3$ & 3.4 & & $3.4(101.4)$ & 26.3 & 1.44 & 0.83 & 83.8 & 23.2 & $23.3(121.3)$ & 19.9 & 1.3 & 0.13 \\
\hline & $c-4$ & 4.3 & & $4.3(102.3)$ & 23.9 & 1.45 & 0.82 & 77.1 & 24.0 & $25.1(123.1)$ & 20.8 & 6.2 & 0.12 \\
\hline & $c-5$ & 3.9 & & $3.9(101.9)$ & 24.2 & 1.43 & 0.85 & 75.4 & 23.3 & $24.2(122.2)$ & 20.3 & 10.3 & 0.07 \\
\hline & $c-6$ & 2.8 & & $2.8(100.8)$ & 19.0 & 1.42 & 0.86 & 58.3 & 20.9 & $22.3(120.3)$ & 19.5 & 26.0 & 0.04 \\
\hline & $c-7$ & 4.1 & & $4.1(102.1)$ & 14.1 & 1.42 & 0.86 & 43.3 & 21.1 & $24.1(122.1)$ & 20.0 & 40.5 & 0.02 \\
\hline & c- 8 & 3.6 & & $3.6(101.6)$ & 11.7 & 1.44 & 0.84 & 36.8 & 20.0 & $24.4(122.4)$ & 20.8 & 45.9 & 0.02 \\
\hline & c-9 & 11 & & $11 \quad(109.0)$ & 3.7 & 1.43 & 0.85 & 11.6 & 16.0 & $30.0(128.0)$ & 19.0 & 70.9 & 0.04 \\
\hline & $\mathrm{c}-10$ & - & & - & 0 & 1.43 & 0.85 & 0 & 20.5 & $20.6(118.6)$ & - & 81.9 & - \\
\hline
\end{tabular}

$※ 1$ The figure of the parenthesis is the absolute pressure, which is added the atmospheric pressure $98 \mathrm{kPa}$ to the mesured pressure.

$※ 2$ Effective stress of Unsaturated soil based on Bishop's equation, parameter of suction $\chi$ represents the degree of saturation.

$※ 3$ Sample was saturated with back pressure of $100 \mathrm{kPa}$.

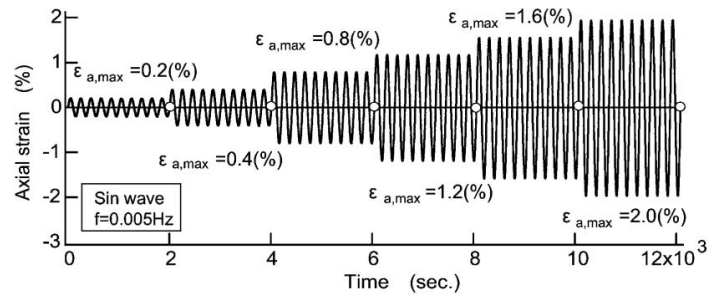

Fig. 5. Time history of axial strain during cyclic loading process

\section{Summary of Testing Conditions}

Table 1 depicts the initial conditions of the triaxial tests after the consolidation process (after the pore water valve and solenoid valve were closed, i.e., just before the cyclic shear process). The initial soil conditions described in Table 1 were the testing parameters: the initial degree of saturation $(0-100 \%)$, the net stress $\left(\sigma_{\text {net } 0}=20 \mathrm{kPa}\right.$ and $60 \mathrm{kPa}$ in target value), the initial relative density $\left(D_{\mathrm{r} 0}=\right.$ $26 \%$ and $60 \%)$ and the suction $(0-10 \mathrm{kPa})$. Here, the test conditions of series a $(a-1 \sim a-13)$, series $b(b-1 \sim b-4)$ and series $\mathrm{c}(\mathrm{c}-1 \sim \mathrm{c}-10)$ are indicated.

- Series-a specimen: the initial relative density is about $60 \%$ and the initial pore water pressure is equal to the atmospheric pressure.

- Series-b specimen: the initial relative density is about $60 \%$ and the initial pore air pressure is equal to the atmospheric pressure.

- Series-c specimen: the initial relative density is about $26 \%$, and the initial pore water pressure is equal to the atmospheric pressure.

The reason for taking two kinds of initial suction states into account is as follows. According to the Japanese Geotechnical Society Standard (JGS-standard 05271998), an initial suction state can be produced to introduce certain pore air pressure, which is usually larger than an atmospheric pressure, to an unsaturated specimen in triaxial shear test. In such a condition, the pore air pressure may be different from the atmospheric pressure. On the other hand, when the suction is at or near the 
ground surface, capillary tension is demonstrated, the pore air pressure is thought to be identical to the atmospheric pressure and the pore water pressure is smaller than the atmospheric pressure. The conditions of series-b correspond to this situation.

\section{Definition of Effective Stress and Effective Stress Reduc- tion Ratio}

It is well known that there are many definitions of an effective stress for unsaturated soils. For simplicity, in this study, we have used Bishop's proposed equation (Bishop et al., 1963) to evaluate the effective stress, as shown in Eq. (1).

$$
\begin{aligned}
& \sigma_{\mathrm{m}}^{\prime}=\left(\sigma_{\mathrm{m}}-u_{\mathrm{a}}\right)+\chi\left(u_{\mathrm{a}}-u_{\mathrm{w}}\right) \\
& s=u_{\mathrm{a}}-u_{\mathrm{w}}
\end{aligned}
$$

In the equation, $u_{\mathrm{a}}, u_{\mathrm{w}}$ and $\chi$ represent the pore air pressure, the pore water pressure, and the material parameter, respectively. The suction $s$ is defined by Eq. (2). Several definitions of parameter $\chi$ have been proposed by many researchers (e.g., Bishop et al., 1963; Karube et al., 1996; Vanapalli et al.,1996; Gallipoli et al., 2002). In this study, parameter $\chi$ adopts the degree of saturation $S_{\mathrm{r}} / 100$. The definition of parameter $\chi$ has been proposed by many researchers. To discuss the effectiveness of the parameter $\chi$ used here during the cyclic shear process, the results using another definition of parameter $\chi$ will be shown in the following section.

By using the above definition, the effective stress reduction ratio during the cyclic shear can be defined as follows:

$$
\text { The effective stress reduction ratio }=1-\frac{\sigma_{\mathrm{m}}^{\prime}}{\sigma_{\mathrm{m} 0}^{\prime}}
$$

where $\sigma_{\mathrm{m} 0}^{\prime}$ is the initial mean effective principal stress. This index indicates the degree of effective stress loss ranging from zero to unity. When the effective stress reduction ratio is 1.0 , the specimen attains complete liquefaction state due to cyclic shear.

\section{TEST RESULTS}

\section{Stress-strain Relationships, Effective Stress Paths and} Suction Behaviors

Figures 6 and 7 show the test results for unsaturated soil with a relatively low degree of saturation. Figure 6 shows the results of the a-4 unsaturated specimen $\left(u_{\mathrm{a} 0}=\right.$ $\left.6.0(104) \mathrm{kPa}, S_{\mathrm{r} 0}=84.6 \%\right)$ and Fig. 7 shows the results for b-2 $\left(u_{\mathrm{w} 0}=-3.1(94.9) \mathrm{kPa}, S_{\mathrm{r} 0}=89.9 \%\right)$. In these figures, (a)-(c) show the stress-strain relationships, the effective stress paths, and the time histories of the pore air and water pressure during cyclic shear, respectively. In figure (c) the difference between $u_{\mathrm{a}}$ and $u_{\mathrm{w}}$, which is indicated by shading, represents suction. Further with a gradual decrease in the peak of the deviator stress with increasing strain amplitude, the stiffness decreased with each loading cycle. Consequently, the mean effective principal stress reached zero. It is noteworthy that, even
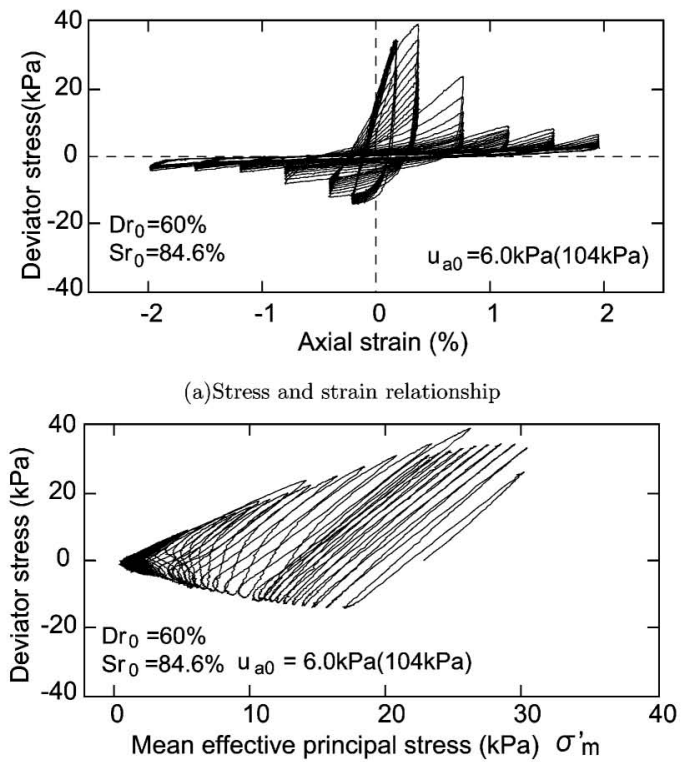

(b)Effective stress path

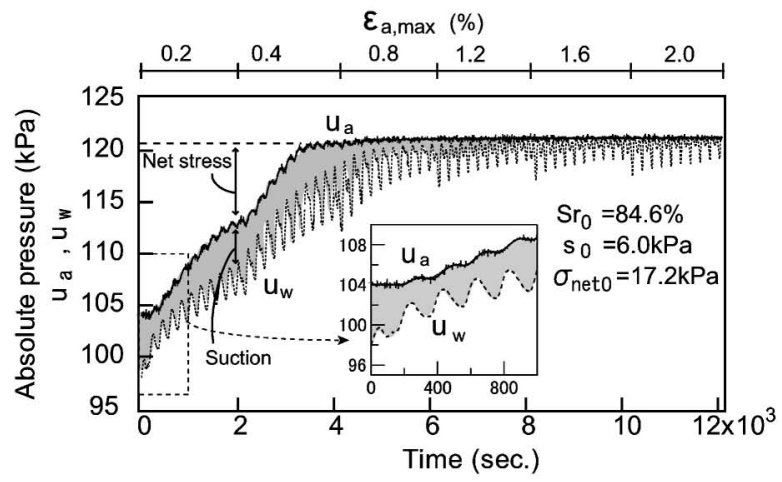

(c) Time history of pore air pressure and pore water pressure

Fig. 6. Test results of unsaturated cyclic shear test (case a-4)

in cases with a considerably small degree of saturation, the soil particle skeleton is degraded by the cyclic shear and reaches a zero effective stress state, thereby causing a failure in the microstructure and engendering the reduction of the soil shear strength. In such a state, the specimen behaves like a liquid.

If we look at the detailed suction behavior shown in Figs. 6(c) and 7(c), firstly, both the pore water pressure and the pore air pressure increased during cyclic loading. In Fig. 6(c), the pore air pressure gradually increased and reached the initial mean confining stress at around 3000 seconds. At this point, the net stress reaches zero. The pore water pressure also gradually increased but with relatively large fluctuations and reached the initial mean confining stress at around 7000 seconds. On the other hand, Fig. 7(c) shows that suction gradually decreased and reached zero at around 3000 seconds. The net stress also gradually decreased and reached zero at around 5000 seconds. At that point, the effective stress was zero. As shown in the results of the two test cases, however, the reduction processes of the two tests were different, and the contribution of the net stress and suction to effective stress were completely diminished in both cases. 


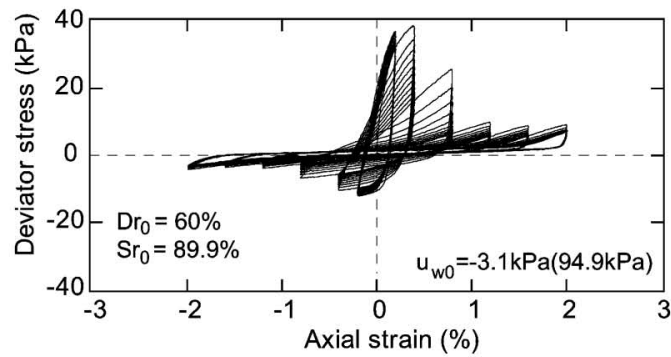

(a)Stress and strain relationship

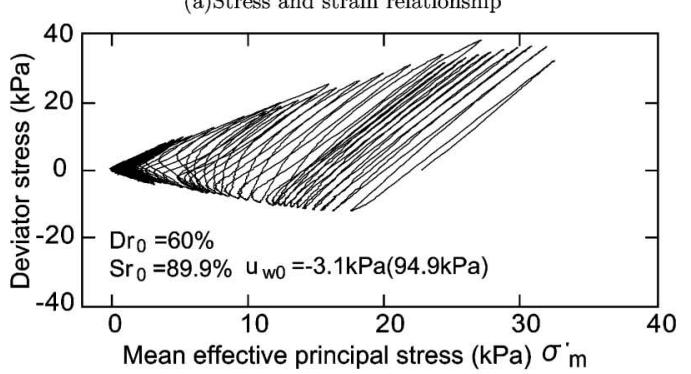

(b)Effective stress path

$$
\varepsilon_{\mathrm{a}, \max }(\%)
$$

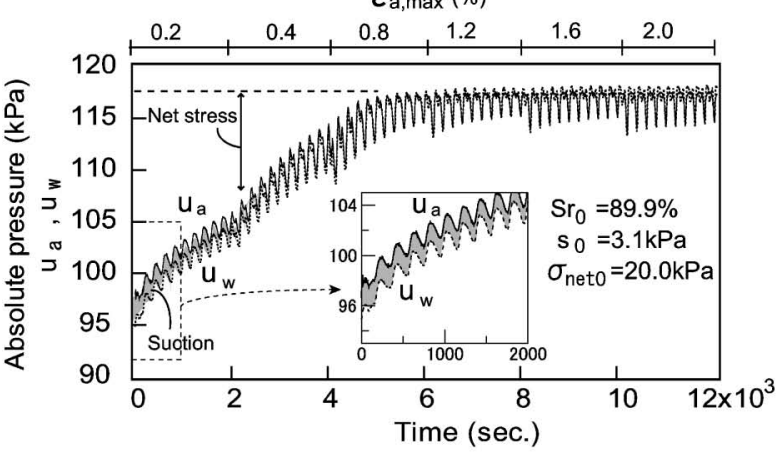

(c)Time history of pore air pressure and pore water pressure

Fig. 7. Test results of unsaturated cyclic shear test (case b-2)

The final state after cyclic shear for all specimens is summarized in Table 2. Figure 8 shows the relationship between the suction and the degree of saturation before and after cyclic shear. Suction decreased during cyclic shear in all test cases and the suction of some specimens reached zero.

It is likely that suction decreases with almost direct proportionality to effective stress loss. However, as can be understood from Eq. (1), zero suction does not imply zero effective stress. Figure 9 shows the example paths of the relationship between suction and mean effective principal stress. As suction decreases according to Eq. (1), the mean effective principal stress decreases. The effective stress of unsaturated soil consists of both effect of soil particle skeleton of the first term and that of the suction of the second term in Eq. (1). It can be seen in Fig. 9 that the mean effective principal stress does not necessarily reach zero when the suction reaches zero in specimens. That is, the effective stress does not reach zero because the effective stress exists due to soil particle skeleton, even if the suction due to meniscus does not contribute to the effective stress.

Here, the parameter $\chi$ in the definition of effective stress is discussed. We confirmed that values of parameter $\chi$ do not affect significantly the summary of this paper. Figure 10 shows the mean effective principal stress which was defined in two different equations. One is the parameter based on the degree of saturation $S_{\mathrm{r}} / 100$ and the other is the parameter based on effective degree of saturation $S_{\mathrm{e}}$. Effective degree of saturation $S_{\mathrm{e}}$ can be estimated from the soil-water characteristic curve data and be defined as follows (e.g., Vanapalli et al., 1996):

$$
S_{\mathrm{e}}=\frac{\theta-\theta_{\mathrm{r}}}{\theta_{\mathrm{s}}-\theta_{\mathrm{r}}}
$$

Where, $\theta$ is volumetric water content and $\theta_{\mathrm{s}}$ is saturated volumetric water content, $\theta_{\mathrm{s}}$ is volumetric water content at residual conditions. With difference between two equations, the test result does not change greatly in Fig. 10.

\section{Effective Stress Reduction Ratio}

Figure 11 shows the time histories of the effective stress reduction ratio for several specimens. As shown in the figures, when the same axial strain history is applied, it is more difficult to bring the effective stress reduction ratio to unity when the degree of saturation is low and the relative density is high. Consequently, the final effective stress after cyclic shear in all cases can be summarized as a function of the initial degree of saturation, as is shown in Fig. 12. The liquefaction of unsaturated soils is affected not only by the volume compressibility of the soil particle structure, which is reflected by dry density, but also by the degree of saturation and the initial confining pressure.

\section{The Pore Ppressure Coefficient B-value before and after} Cyclic Shear

The pore pressure coefficient $B$-value has been used to quantify the degree of saturation. According to the past studies (e.g., Yoshimi et. al., 1989; Grozic et al., 1999), when the pore pressure coefficient $B$-value drops to zero level, the degree of saturation decreases by about $90 \%$. Also in this research, the pore pressure coefficient $B$ values before cyclic shear were very small in comparison with the full saturation case shown in Table 1. To confirm the change of the pore pressure coefficient, we measured the $B$-value once again after cyclic shear. Figure 13 shows the change in the pore pressure coefficient $B$-value before and after cyclic shear. In the test, because of the decreasing volume of the specimen during the test, the degree of saturation increases after cyclic shear. It is clear that, for all unsaturated specimens, with the exception of the dry and the almost saturated specimen, the pore pressure coefficient $B$-value increased after cyclic shear. Even in cases where the degree of saturation is less than $100 \%$, the pore pressure coefficient $B$-value of the liquefied specimen indicated a high value.

Figure 14 illustrates an example of the cell pressure, pore air pressure, pore water pressure and void ratio when measuring the pore pressure coefficient of the liquefied specimen. Even when the degree of saturation was not $100 \%$, at the liquefaction state, the pore water and the air pressure responses synchronized with the increase 
Table 2. Test results after cyclic loading

(a) $D_{\mathrm{r} 0}=60 \%$

\begin{tabular}{|c|c|c|c|c|c|c|c|c|c|c|}
\hline $\begin{array}{c}\text { Test } \\
\text { sample }\end{array}$ & $\begin{array}{l}\text { Case } \\
\text { No }\end{array}$ & $\begin{array}{l}\text { Suction } \\
u_{\mathrm{a}-} u_{\mathrm{w}} \\
(\mathrm{kPa})\end{array}$ & $\begin{array}{c}\text { Pore water } \\
\text { pressure }{ }^{\star 1} \\
u_{\mathrm{w}}(\mathrm{kPa})\end{array}$ & $\begin{array}{c}\text { Pore air } \\
\text { pressure }^{※ 1} \\
u_{\mathrm{a}}(\mathrm{kPa})\end{array}$ & $\begin{array}{c}\text { Dry density } \\
\rho_{\text {d, cyc }}\left(\mathrm{g} / \mathrm{cm}^{3}\right)\end{array}$ & $\begin{array}{c}\text { Void } \\
\text { ratio } \\
e_{\text {cyc }}\end{array}$ & $\begin{array}{c}\text { Degree of } \\
\text { saturation } \\
S r_{\text {cyc }}(\%)\end{array}$ & $\begin{array}{c}\text { MEPS* } \\
\sigma_{\mathrm{m}}^{\prime}(\mathrm{kPa})\end{array}$ & $\begin{array}{l}\text { Effective stress } \\
\text { redusction ratio } \\
1-\left(\sigma_{\mathrm{m}}^{\prime} / \sigma_{\mathrm{m} 0}^{\prime}\right)\end{array}$ & $\begin{array}{c}B \text {-value } \\
B\end{array}$ \\
\hline \multirow{14}{*}{$\begin{array}{c}\text { Toyoura } \\
\text { asnd } \\
\left(D_{\mathrm{r} 0}=60 \%\right)\end{array}$} & $a-2$ & 0.0 & $22.1(120.1)$ & $22.1(120.1)$ & 1.52 & 0.75 & 94.5 & 0.0 & 1.00 & 1.00 \\
\hline & $a-3$ & 0.0 & $20.7(118.7)$ & $20.7(118.7)$ & 1.52 & 0.74 & 94.6 & 0.0 & 1.00 & 1.00 \\
\hline & $a-4$ & 0.0 & $23.3(121.3)$ & $23.3(121.3)$ & 1.54 & 0.72 & 85.8 & 0.2 & 0.99 & 1.00 \\
\hline & $a-6$ & 0.8 & $23.9(121.9)$ & $24.7(122.7)$ & 1.55 & 0.70 & 68.6 & 0.9 & 0.96 & 0.22 \\
\hline & $a-7$ & 1.7 & $17.0(115.0)$ & $18.7(116.7)$ & 1.56 & 0.69 & 54.8 & 8.8 & 0.58 & 0.16 \\
\hline & $a-8$ & 6.4 & $8.9(106.9)$ & $15.3(113.3)$ & 1.55 & 0.70 & 33.1 & 16.7 & 0.20 & 0.02 \\
\hline & $a-9$ & 9.5 & $6.9(104.9)$ & $16.4(114.4)$ & 1.55 & 0.71 & 20.6 & 21.0 & 0.01 & 0.03 \\
\hline & $a-10$ & - & - & - & 1.60 & 0.65 & 0.0 & 28.6 & 0.00 & - \\
\hline & $a-11$ & 0.3 & $57.3(155.3)$ & $57.6(155.6)$ & 1.56 & 0.69 & 86.5 & 6.9 & 0.89 & 0.93 \\
\hline & $a-12$ & 0.0 & $55.5(153.5)$ & $55.5(153.5)$ & 1.57 & 0.69 & 84.2 & 8.2 & 0.87 & 0.80 \\
\hline & $a-13$ & 2.8 & $18.0(116.0)$ & $20.8(118.8)$ & 1.58 & 0.68 & 49.9 & 59.2 & 0.01 & 0.05 \\
\hline & $b-2$ & 0.0 & $20.0(118.0)$ & $20.0(118.0)$ & 1.53 & 0.73 & 91.1 & 0.2 & 1.00 & 0.97 \\
\hline & $b-3$ & 1.0 & $19.2(117.6)$ & $20.2(118.2)$ & 1.55 & 0.70 & 66.4 & 2.0 & 0.90 & 0.87 \\
\hline & $b-4$ & 3.5 & $15.7(113.7)$ & $12.4(110.4)$ & 1.56 & 0.68 & 42.9 & 8.1 & 0.63 & 0.05 \\
\hline
\end{tabular}

$※ 1$ The figure of the parenthesis is the absolute pressure, which is added the atmospheric pressure $98 \mathrm{kPa}$ to the mesured pressure. MEPS*-mean effective principal stress using Bishop's equation

(b) $D_{\mathrm{r} 0}=60 \%$

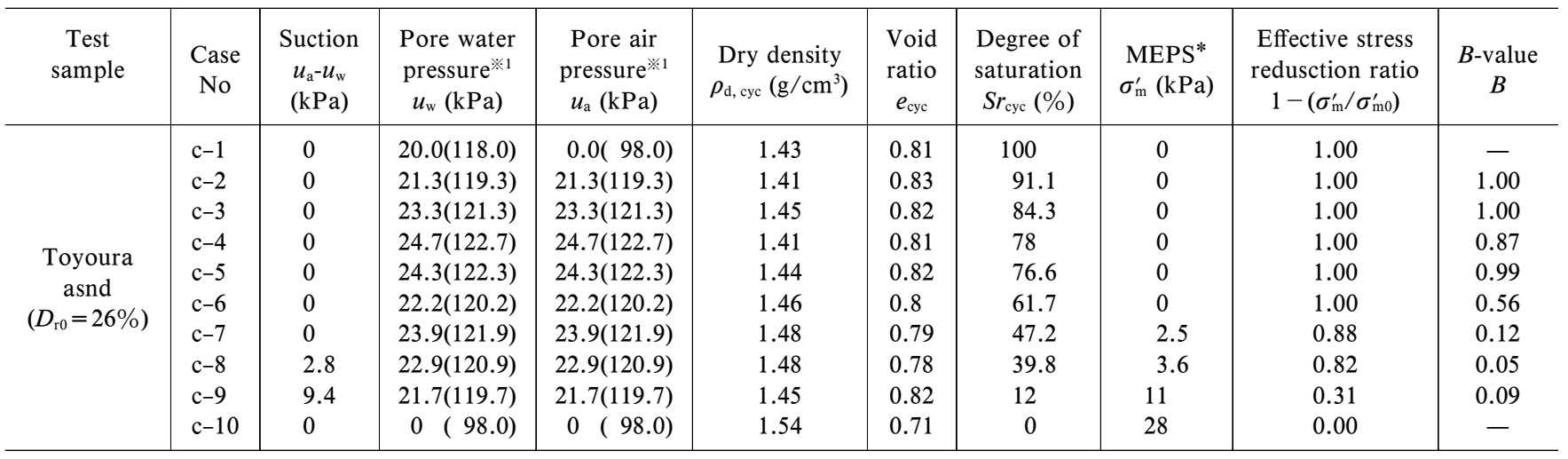

$※ 1$ The figure of the parenthesis is the absolute pressure, which is added the atmospheric pressure $98 \mathrm{kPa}$ to the mesured pressure. MEPS* - mean effective principal stress using Bishop's equation

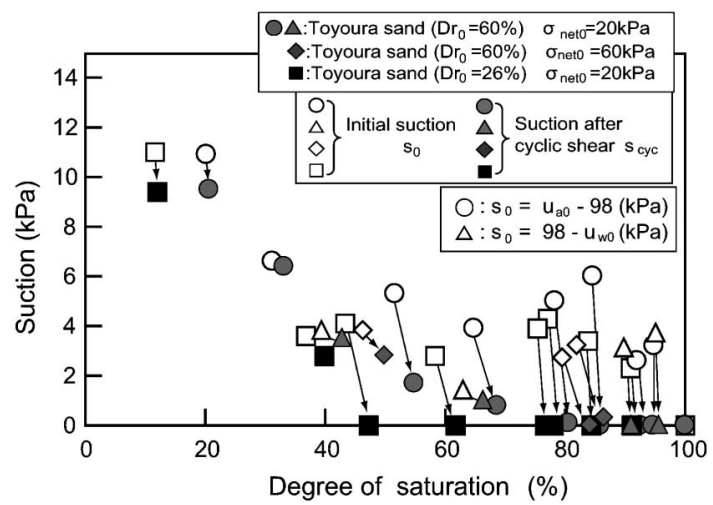

Fig. 8. Change of suction between before and after cyclic loading history

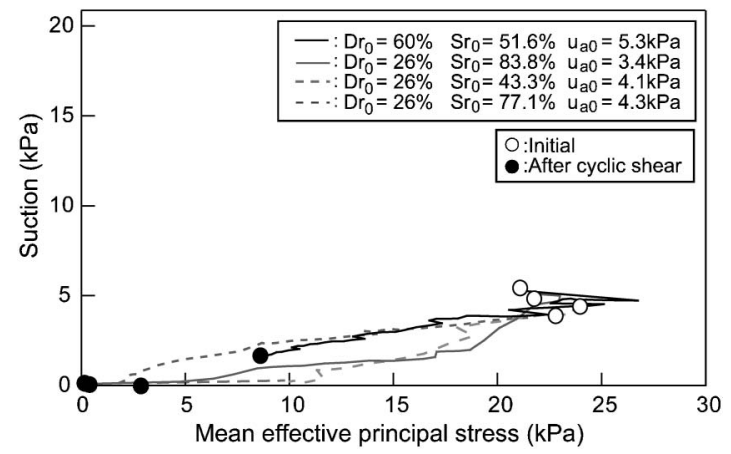

Fig. 9. Example of relatinship between suction and mean effective principal stress 


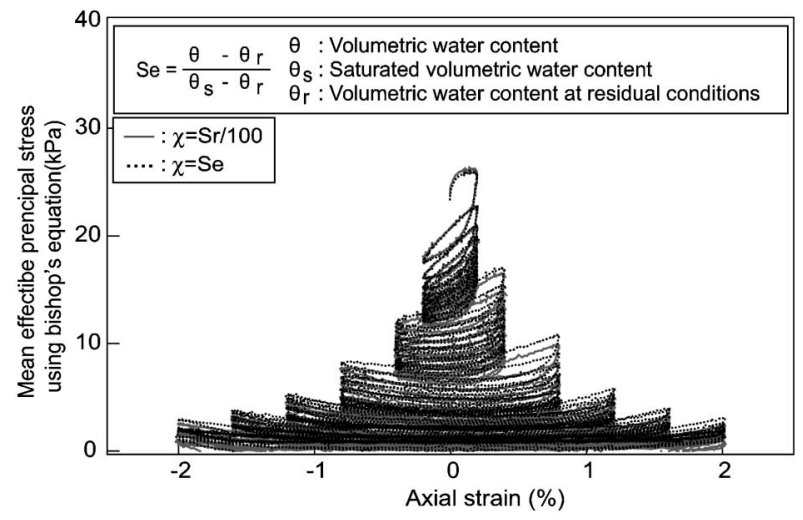

Fig. 10. Difference in the parameter $\chi$ in mean effective principal stress
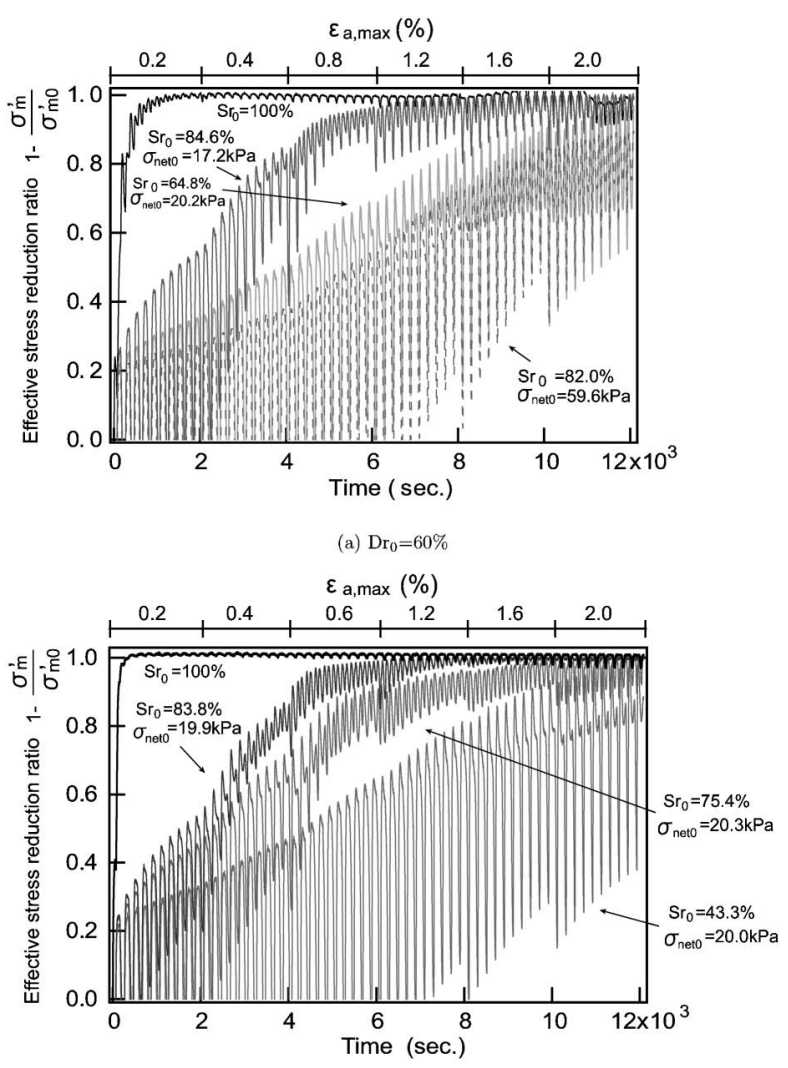

(b) $\mathrm{Dr}_{0}=26 \%$

Fig. 11. Example of time histories of effective stress reduction ratio

of cell pressure, and the pore pressure coefficient was unity. It can be seen that the specimen void ratio changed as the pressure changed after cyclic shear, as is shown in Fig. 14(b). On the other hand, volume change was not observed in specimens before cyclic shear, as is shown in Fig. 14(a). Therefore, it is thought that the soil particle skeleton degraded to the extent that it was easy to compress because of liquefaction. In conclusion, even if the specimen has a low degree of saturation, such as $60-90 \%$, which is often discussed in the liquefaction problem, when the soil particle structure is destroyed, the value of the pore pressure coefficient $B$-value approaches unity.

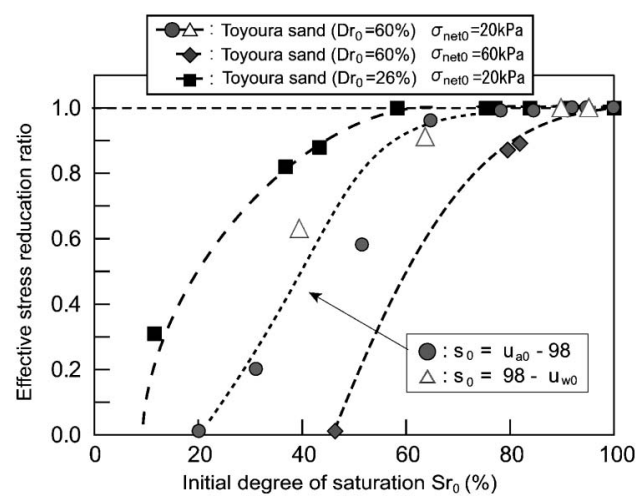

Fig. 12. Effective stress reduction ratio versus the initial degree of saturation

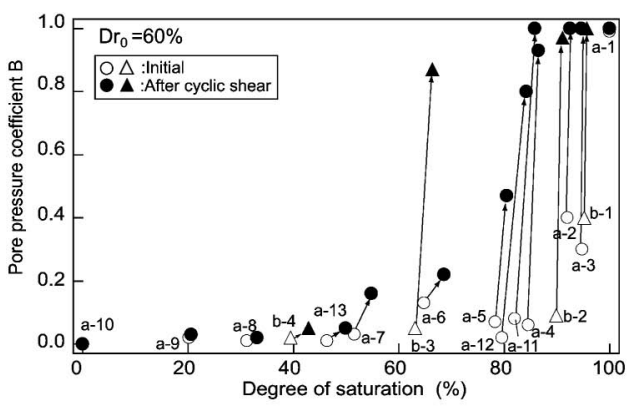

(a) $\operatorname{Dr}_{0}=60 \%$

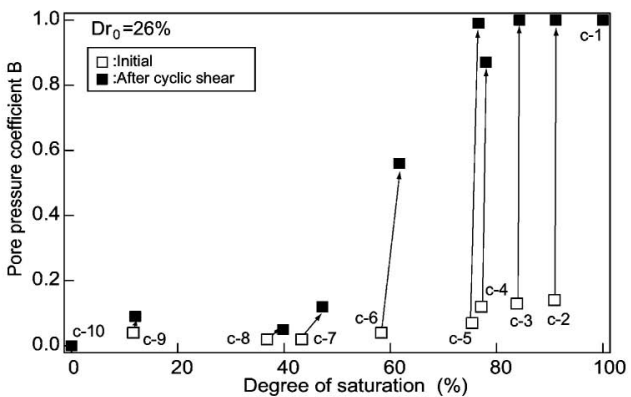

(b) $\mathrm{Dr}_{0}=26 \%$

Fig. 13. Pore pressure coefficient $B$ versus degree of saturation

\section{LIQUEFACTION STATE OF UNSATURATED SAND}

Even under the unsaturated condition, specimens with a highly compressible soil particle structure may lose effective stress due to cyclic shear and may reach the liquefaction state. Based on the test results and Eq. (1), it can be understood that the complete liquefaction state for unsaturated soils is achieved when both the pore air and water pressure are the same as the initial total confining pressure. Here, the suction reaches zero when the specimen becomes liquefied, and so the effective stress reaches zero, which is irrelevant to the parameter $\chi$ of Eq. (1).

If the pore air can be assumed to be an ideal gas, a consideration of the volume change of pore air between the initial and final full liquefaction states should establish the following relation from the Boyle-Charles law. 


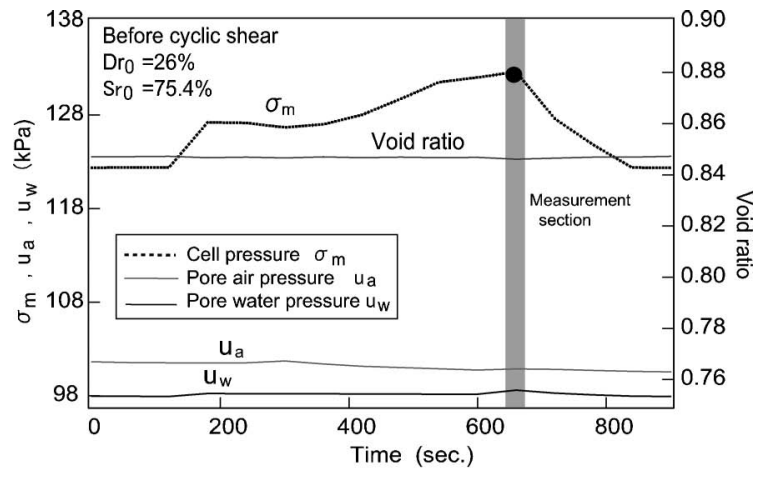

(a) Before cyclic shear

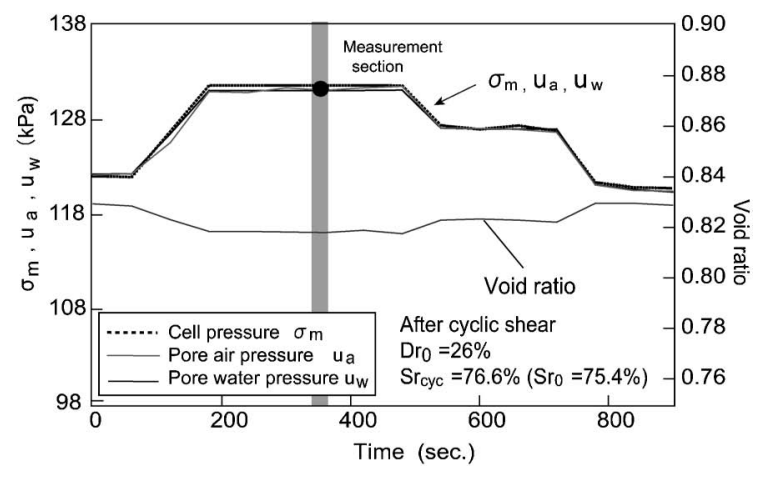

(b) After cyclic shear

Fig. 14. Time histories of cell pressure, pore air pressure, pore water pressure and void raito before and after cyclic shear

$$
u_{\mathrm{a} 0} V_{\mathrm{a} 0}=u_{\mathrm{a}, \text { liq }}\left(V_{\mathrm{a} 0}-\Delta V_{\mathrm{a}}\right)=\text { const. }
$$

where $V_{\mathrm{a} 0}$ is the initial volume of pore air. It should be noted that pore air pressure is an absolute value including atmospheric pressure. Equation (5) should be established not only in the initial and final state, but also in the optional time during cyclic shear. Figure 15 shows an example of the variations of the product of pore air pressure and volume during cyclic shear. It can be seen that the values are almost constant, meaning that Eq. (5) is also established during cyclic shear.

When there is zero effective stress state in Eq. (1), the pore air and water pressure should be equal to the initial total pressure. Thus, $u_{\mathrm{a}}$ liq can be replaced by $\sigma_{\mathrm{m} 0}$ in Eq. (5); the following relationship is established in the zero effective stress state (i.e., liquefaction state of unsaturated soil).

$$
u_{\mathrm{a} 0} V_{\mathrm{a} 0}=\sigma_{\mathrm{m} 0}\left(V_{\mathrm{a} 0}-\Delta V_{\mathrm{a}}\right)
$$

Under the undrained condition, the volume change of pore air $\Delta V_{\mathrm{a}}$ is equal to the volume change of the soil particle structure, which represents the volume change required to cause complete liquefaction. Here, since the volume compressibility of air is significantly larger than that of soil particles and water, soil particles and water are assumed to be incompressible. From Eq. (6), because the volume change $\Delta V_{\text {a }}$ corresponds to the void ratio change $e_{0}-e_{\text {liq }}$, the relationship expressed in Eq. (6) can be rewritten as follows:

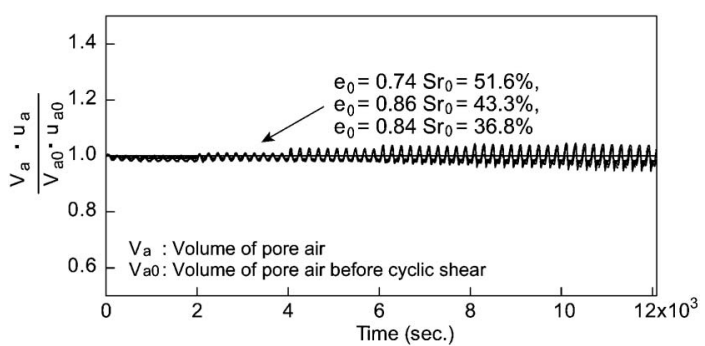

Fig. 15. Example of time histories of the product of pore air pressure and volume

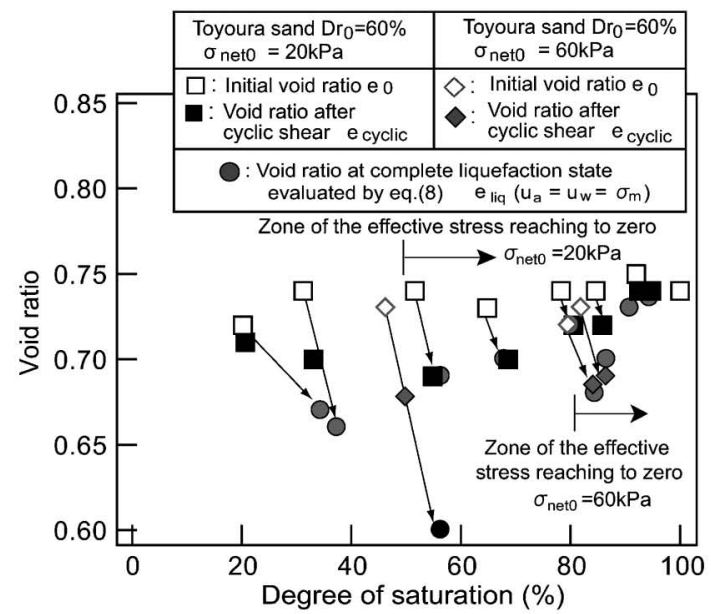

(a) $\left(\mathrm{Dr}_{0}=60 \%\right)$

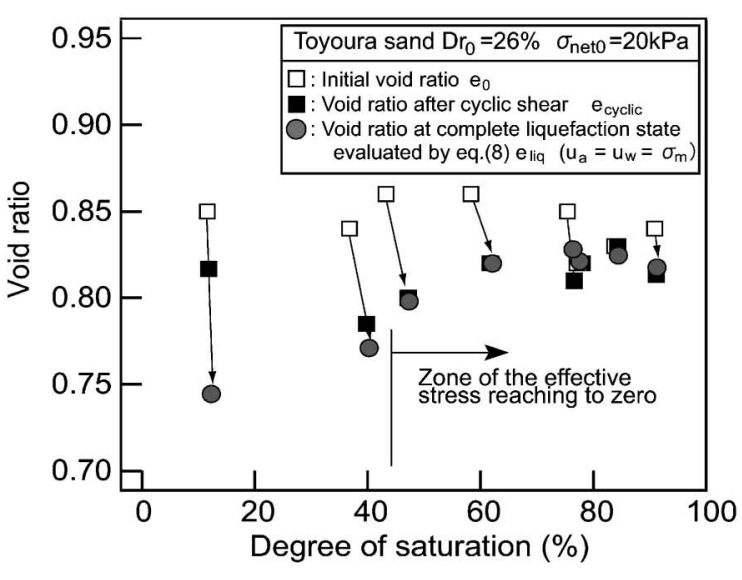

(b) $\left(\mathrm{Dr}_{0}=26 \%\right)$

Fig. 16. Change of void ratio during cyclic shear required to reach liquefaction state

$$
\begin{aligned}
& e_{0}-e_{\mathrm{liq}}=\left(1-\frac{S_{\mathrm{r} 0}}{100}\right)\left(1-\frac{u_{\mathrm{a} 0}}{\sigma_{\mathrm{m} 0}}\right) e_{0} \\
& e_{\mathrm{liq}}=\left(\frac{u_{\mathrm{a} 0}}{\sigma_{\mathrm{m} 0}}+\frac{S_{\mathrm{r} 0}}{100}-\frac{u_{\mathrm{a} 0}}{\sigma_{\mathrm{m} 0}} \frac{S_{\mathrm{r} 0}}{100}\right) e_{0}
\end{aligned}
$$

Here, $e_{\text {liq }}$ is the void ratio at the zero effective stress state, in which both pore air and water pressure are identical to the initial mean total confining pressure. It can be under- 
stood that the void ratio change required to cause liquefaction is a function of the initial degree of saturation, the confining stress, and initial pore pressure. From Eq. (7), as was mentioned earlier, liquefaction is more likely to occur as the initial degree of saturation is high and as the initial effective stress is low, and only a small volume change is required to cause liquefaction.

Figure 16 shows the relationship between the void ratio and the degree of saturation before and after cyclic shear. In the figure, the circle mark $e_{\text {liq }}$ depicts the void ratio change required to obtain a state of complete liquefaction as calculated by Eq. (8). Since the structure of the soil is loose, the soils liquefy easily because of their high compressibility. It can be seen that the test specimens reached the liquefaction state when the void ratio after cyclic shear $e_{\text {cyclic }}$ was equivalent to $e_{\text {liq }}$. On the other hand, the sample did not reach liquefaction state in cases where the $e_{\text {cyclic }}$ did not reach $e_{\text {liq }}$. Approximate zone of degree of saturation which is estimated to become liquefaction with cyclic shear, based on the change of volume, is shown as "zone of the effective stress reaching zero"' in Fig. 16.

\section{LIQUEFACTION POTENTIAL ASSESSMENT FOR UNSATURATED SOIL GROUND}

Based on the discussion in the previous section, the liquefaction potential of unsaturated soil ground can be evaluated by comparing the volume compressibility of the soil particle skeleton and the air volume change required to reach a zero effective stress state. In this section, a new scheme to evaluate the liquefaction potential of unsaturated soil is proposed based on the concept that the compressibility of the soil can be taken into consideration.

\section{Volume Compressibility of Soil Subjected to Cyclic Shear History}

Volume compressibility under cyclic shear is the key issue in the liquefaction of unsaturated soil. In order to evaluate the volume compressibility of soil, the authors studied the volume change of sand subjected to cyclic shear (Unno et al., 2006c). In the study, several series of strain-controlled cyclic shear triaxial tests were carried out under both undrained and drained conditions, and the volume change of the soils under the drained cyclic shear was compared with those reconsolidated after the undrained cyclic shear with the same shear strain history.

Figures 17 and 18 show the volume change of samples under the same cyclic shear history and with the same initial density. Figure 17(a) shows the volume change during the cyclic shear for dry sand under the drained condition. As shown in the figure, the void ratio decreases gradually with increasing strain history. Figure 17(b) shows the volume change during the reconsolidation process after undrained cyclic shear in the case of full-saturated sand. Decrease in the void ratio was observed as the strain history increased. It is known that the accumulated shear strain path is an effective index to represent the degree of shear strain history (Sento et al., 2003). The accumulated

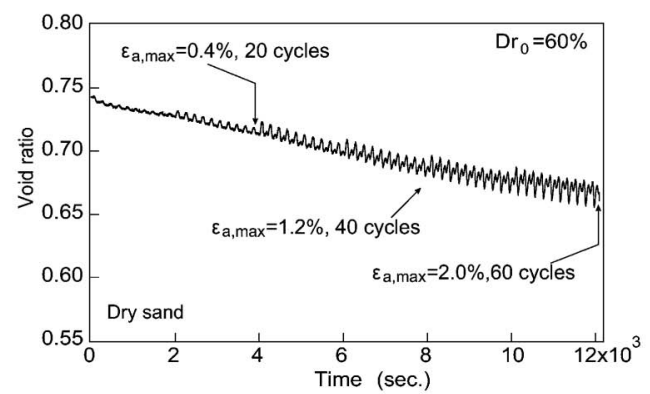

(a)Volume change of dry sand during cyclic shear

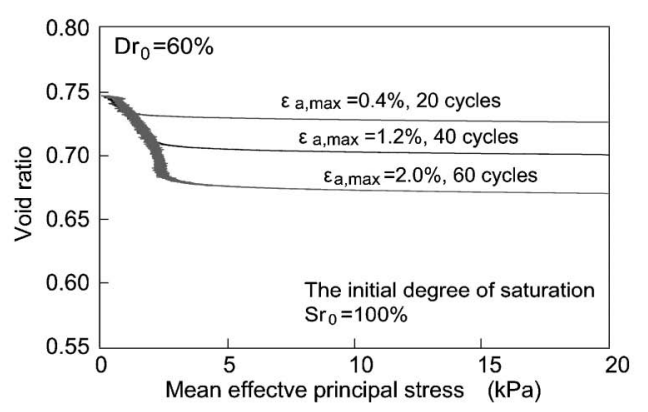

(b)Volume compression of saturated sand under reconsolidation after cyclic shear

Fig. 17. Maximum volume compression of sand under same cyclic shear history

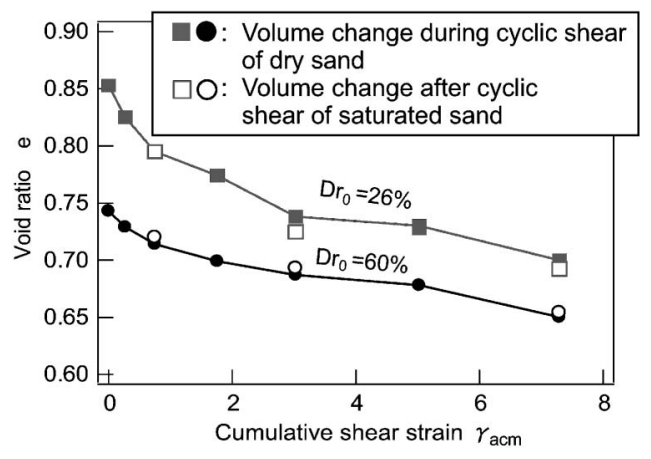

Fig. 18. Relationship of volumetric compression between drained cyclic shear and reconsolidation after undrained cyclic shear

shear strain is defined by the following equation.

$$
\gamma_{\mathrm{acm}}=\int|\dot{\gamma}(t)| d t
$$

Here, $\dot{\gamma}(t)$ is the velocity of the shear strain at time $t$. In the following discussion, it is assumed that such a relationship also exists under the unsaturated condition.

Figure 18 shows the comparison of volume change between two kinds of drainage conditions. Under the same cyclic shear strain histories, the laboratory test results illustrated that the volumetric strain in the drained cyclic shear test of dry sand was the same in the reconsolidation test after the undrained cyclic shear of saturated sand. The volumetric change under cyclic shear depended only on the strain history and not on the stress path. Considering that volume change due to particle rearrangement is determined only by geometrical deformation, the behavior seems acceptable. In addition, the initial void ratio of 


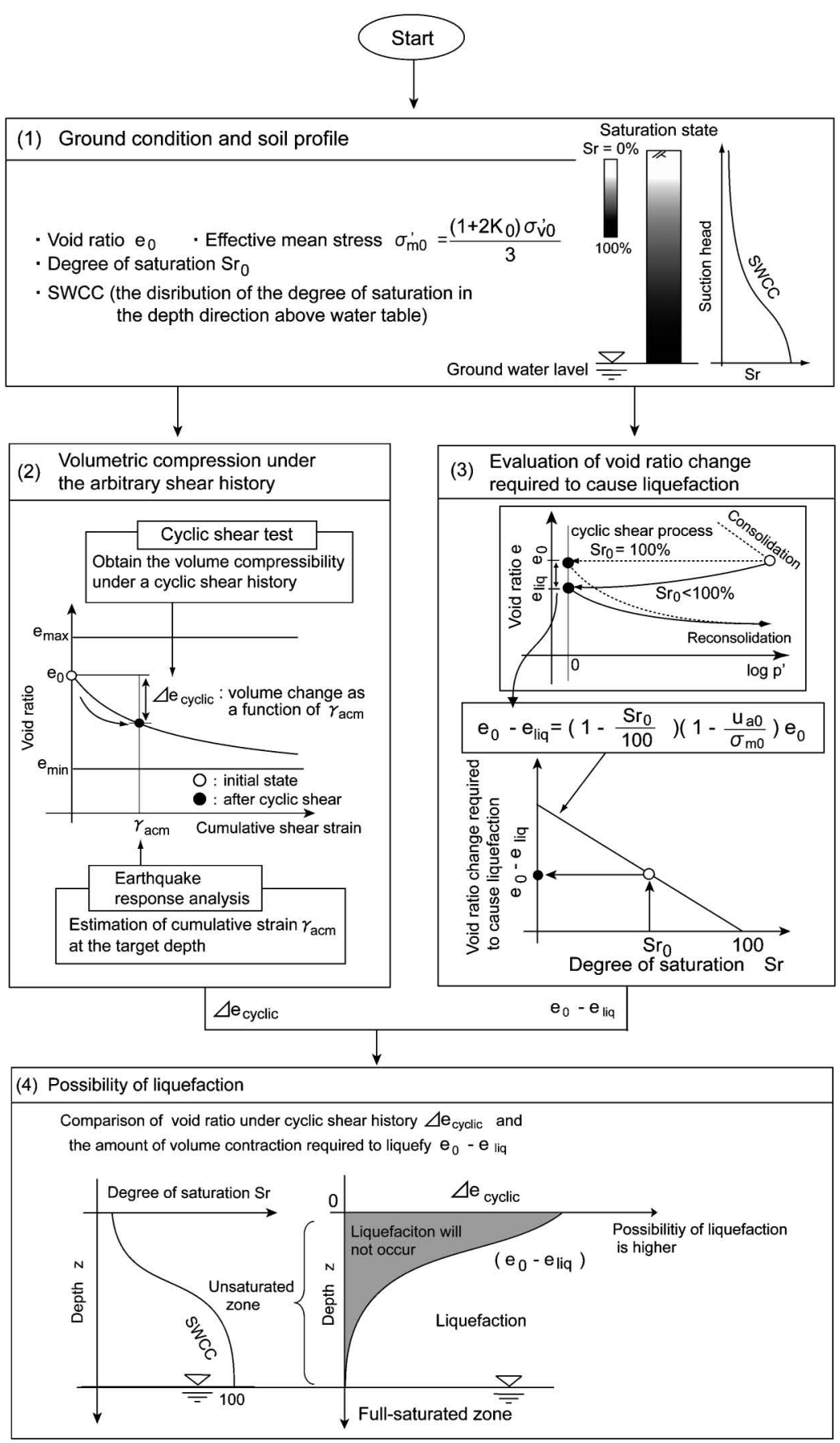

Fig. 19. Assesment flow of liquefaction potential of unsaturated sand

the samples had small influences on the volume change pattern with shear strain history. In both test cases the larger the initial void ratio becomes, the larger the amount of change in the void ratio becomes. Moreover, when cumulative shear strain was about 7.5 , the void ratio does not reach the void ratio in densest state of Toyoura sand $(=0.609)$ obtained from the standard test procedure (JGS standard, JGS 0161). Regarding the void ratio due to cyclic shear, another literature written by the authors (Unno et al., 2006c) is referred to. In conclusion, the void ratio change $\Delta e_{\text {cyclic }}$ during arbitrary cyclic shear history can be obtained by the drained cyclic shear test for dry sand rather than the reconsolidation test after un- drained cyclic shear in the case of fully saturated sand.

\section{Proposed Method}

Figure 19 shows a new assessment scheme of the liquefaction potential for unsaturated soil ground as a function of the degree of saturation. The concept and procedure are explained below:

(1) The ground conditions are given as assessment parameters, and include the dry density, the total stress $\sigma_{\mathrm{m}}$ and the shear wave velocity as well as others. Here, if the soil-water characteristic curve (SWCC) is given by laboratory test for the soils, the distribution of the degree of saturation in the depth direction 
above the water table is estimated as shown in Fig. 19(1).

(2) The void ratio change of the soils subjected to an arbitrary shear history is obtained from the cyclic shear test under the dry condition described in the previous section. If the accumulated shear strain $\gamma_{\text {acm }}$ in the ground generated by the design earthquake can be obtained from a certain earthquake response analysis, by using the relationship between $\gamma_{\text {acm }}$ and the void ratio, $\gamma_{\mathrm{acm}}$ can be used to evaluate the void ratio change $\Delta e_{\text {cyclic }}$ of soils expected for the designed seismic loads. This is shown in Fig. 19(2).

(3) In the case where the initial pore water pressure is assumed to be the atmospheric pressure $u_{\mathrm{a} 0}=98 \mathrm{kPa}$, the amount of volume contraction required to reach the zero effective stress state $\left(e_{0}-e_{\text {liq }}\right)$ can be calculated by Eq. (7) in Fig. 19(3).

(4) Finally, a comparison of the $\Delta e_{\text {cyclic }}$ and $\left(e_{0}-e_{\text {liq }}\right)$ can be used to evaluate the possibility of liquefaction occurrence at the target depth. Naturally, in the case of $\Delta e_{\text {cyclic }}<\left(e_{0}-e_{\text {liq }}\right)$, liquefaction will not occur. On the contrary, in case of $\Delta e_{\text {cyclic }}>\left(e_{0}-e_{\mathrm{liq}}\right)$, the possibility of liquefaction occurrence will be higher with larger differences. Furthermore, the assessment of the depth direction will provide a zone with high liquefaction potential.

To confirm the applicability of the assessment method proposed, we have compiled the laboratory test results of test series-a without the seismic load consideration. That is, in the actual condition, the cyclic shear strain should be given for a designed seismic load, but in our investigation this process was ignored and the same shear strain history was applied as the seismic load. Figure 20 shows the volume change of the test specimens versus the degree of saturation both before and after cyclic shear. In the figure, the volume changes of some of the specimens are plotted after undrained cyclic shear. For example, in the full saturation case, the specimen shows no volume change during cyclic shear and the volume change occurred only during reconsolidation process. From the results, it can be seen that the boundary between non-liquefaction and liquefaction is in good agreement with the theoretical boundary evaluated. In conclusion, the

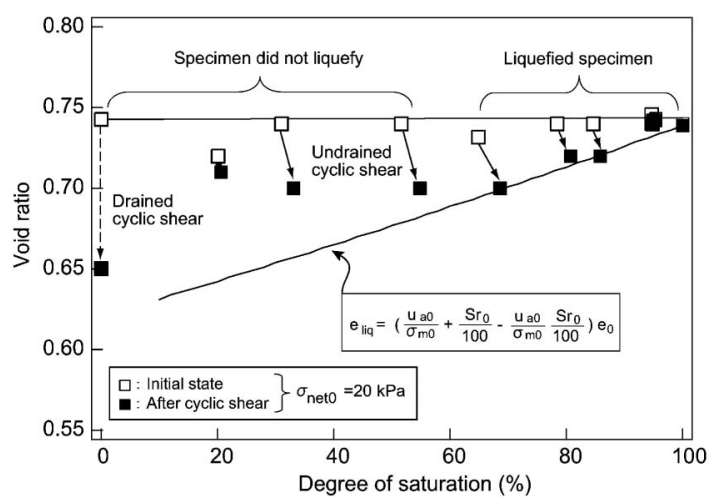

Fig. 20. Liquefaction prediction of the test result using Toyoura sand $\left(D_{\mathrm{r} 0}=60 \%\right)$ proposed method performs well.

Water characteristics of the field situation sometimes exists between SWCC of dry process and that of wetting process. And estimation of precise SWCC of field situation is referred to other researches (e.g., Scott et al., 1983). Besides, if precise water state is required, it is desirable to measure directly state of object area with the moisture sensor and tensiometer.

\section{CONCLUSIONS}

In this paper, the authors discussed the general liquefaction state of unsaturated soils. Furthermore, a new method was proposed to evaluate the liquefaction potential based on our findings of the liquefaction mechanism of unsaturated soils. The conclusions can be summarized as follows:

1) By using the definition of the effective stress proposed by Bishop for unsaturated sand, in which the contributions to the effective stress consists of a net stress and a suction, the liquefaction state for unsaturated soils can be defined as the zero effective stress state, as is the case for saturated soils. From the experimental and theoretical discussions, the zero effective stress state for unsaturated sand is established when both the pore air and water pressure build up and become equal with the initial total pressure.

2) Our test results reveal that, even in the case where the degree of saturation is quite small, the soil particle skeleton is degraded by cyclic shear and reaches a zero effective stress state, thereby causing a failure of the microstructure and engendering the reduction of the soil shear strength. In such a state, the specimen behaves like a liquid, in the same manner as a saturated specimen. In other words, even if the soil is unsaturated, the soil reaches a zero effective stress state under certain conditions.

3) To increase the pore air pressure, a certain volume change of the soil particle skeleton is necessary. The amount of volume change required to reach the zero effective stress state depends on the volume compressibility of the soil particle skeleton, the degree of saturation and the initial confining pressure. In addition, the required volume change can be calculated by the Boyle-Charles law.

4) By comparing the volume compressibility of the soil particle skeleton and the volume change required to cause liquefaction, the liquefaction potential of unsaturated soil can be evaluated. The proposed method to laboratory tests showed good performance when applied to a laboratory test.

\section{REFERENCES}

1) Becker, T. and Meißner, H. (2002): Direct suction measurement in cyclic triaxial test devices, Proc. 3rd Int. Conf. on Unsaturated Soils, 459-462.

2) Bishop, A. W. and Blight, G. E. (1963): Some aspects of effective stress in saturated and partly saturated soils, Geotechnique, 13(3), 
177-197.

3) Gallipoli, D., Gens, A., Vanet, J. and Romero, E. (2002): Role of degree of saturation on the normally consolidated behavior of unsaturated soils, Proc. 3rd Int. Conf. on Unsaturated Soils, 115-120.

4) Grozic, J. L., Robertson, P. K. and Morgenstern, N. R. (1999): Cyclic liquefaction of loose gassy sand, Can. Geotech. J., 37, 843-856.

5) Japanese Geotechnical Standards 0527-1998 (1998).

6) Karube, D., Kato, S., Hamada, K. and Honda, M. (1996): The relationship between mechanical behavior and the state of pore water in unsaturated soil, Journal of Geotechnical Engineering, JSCE, (535/ III-34), 83-92 (in Japanese).

7) Kazama, M., Yanagisawa, E. and Yamaguchi, A. (2000): Liquefaction resistance from a ductility viewpoint, Soils and Foundations, 40(6), 47-60.

8) Kazama, M., Takamura, H., Unno, T., Sento, N. and Uzuoka, R. (2006): Liquefaction mechanism of unsaturated volcanic sandy soils, Journal of Geotechnical Engineering, JSCE, 62(2), 546-561 (in Japanese).

9) Konagai, K., Johannson, J., Mayorca, P., Yamamoto, T., Miyajima, M., Uzuoka, R., Pulido, E. N., Duran, F. C., Sassa, K. and Fukuoka, H. (2002): Las Colinas landslide caused by the January 13, 2001 off the coast of El Salvador earthquake, Journal of Japan Association for Earthquake Engineering, 2(1), 1-15.

10) Nakayama, Y., Nishigata, T., Araki, S., Nishida, K. and Yoshioka, T. (2003): Behavior of unsaturated decomposed granite soil under the repeated loading, Proc. 38th Annual Convention of Japanese Geotechnical Society, 491-492 (in Japanese).

11) Okamura, M. and Soga, Y. (2006): Effects of pore fluid compressibility on liquefaction resistance of partially saturated sand, Soils and Foundations, 46(5), 93-104.

12) Scott, P. S., Farquhar, G. J. and Kouwen, N. (1983): Hysteretic effects on net infiltration, In Advances in Infiltration American Soc. of Agric. Engineers, (11-83), 63-170.

13) Selim, A. A. and Burak, G. (2006): Cyclic stress-strain behavior of partially saturated soils, Proc. 3rd Int. Conf. on Unsaturated Soils, 497-507.

14) Sento, N., Kazama, M. and Uzuoka, R. (2004): Experiment and idealization of the volumetric compression characteristics of clean sand after undrained cyclic shear, Journal of Geotechnical Engineering, JSCE, (764/III-67), 307-317 (in Japanese).

15) Tsukamoto, Y., Ishihara, K., Nakazawa, H., Kamada, K. and Huang, Y. (2002): Resistance of partly saturated sand to liquefaction with reference to longitudinal and shear wave velocities, Soils and Foundations, 42(6), 93-104.

16) Unno, T., Kazama, M., Uzuoka, R. and Sento, N. (2006a): Change of moisture and suction properties of volcanic sand induced by shaking disturbance, Soils and Foundations, 46(4), 519-528.

17) Unno, T., Kazama, M., Sento, N. and Uzuoka, R. (2006b): Cyclic shear behavior of unsaturated volcanic sandy soil under various suction conditions, Proc. 3rd Int. Conf. on Unsaturated Soils, $1133-1144$.

18) Unno, T., Kazama, M., Uzuoka, R. and Sento, N. (2006c): Relation of volumetric compression of sand between under drained cyclic shear and reconsolidation after undrained cyclic shear, Journal of Geotechnical Engineerin, JSCE, 62(4), 757-766 (in Japanese).

19) Uzuoka, R., Sento, N., Kazama, M. and Unno, T. (2005): Landslides during the earthquakes on May 26 and July 26, 2003 in Miyagi, Soils and Foundations, 45(4), 149-163.

20) Vanapalli, S. K., Fredlund, D. G., Pufahl, D. E. and Clifton, A. W. (1996): Model for the prediction of shear strength with respect to soil suction, Canadian Geotechnical Journal, 33(3), 379-392.

21) Yoshimi, Y., Tanaka, K. and Tokimatsu, K. (1989): Liquefaction resistance of a partially saturated sand, Soils and Foundations, 29(3), 157-162. 